DOI: 10.46340/eujem.2020.6.5.16

Oleh Kuzmin, ScD in Economics

ORCID ID: http://orcid.org/0000-0002-6014-6437

Institute of Economics and Management of Lviv Polytechnic National University, Ukraine

Olexandr Yemelyanov, ScD in Economics

ORCID ID: http://orcid.org/0000-0002-1743-1646

Institute of Economics and Management of Lviv Polytechnic National University, Ukraine

Oksana Zhyhalo

ORCID ID: http://orcid.org/0000-0002-8874-3276

Institute of Economics and Management of Lviv Polytechnic National University, Ukraine

\title{
THE ESSENCE OF THE INNOVATION CAPACITY OF ENTERPRISES, METHODS, AND INDICATORS OF ITS EVALUATION
}

\author{
Олег Кузьмін, д. е. н. \\ Олександр Ємельянов, д. е. н. \\ Оксана Жигало \\ Інститут економіки і менеджменту Національного університету "Львівська \\ політехніка», Україна
}

\section{СУТНІСТЬ ІННОВАЦИЙНОЇ ЄМНОСТІ ПІДПРИЕМСТВ, МЕТОДИ ТА ПОКАЗНИКИ ЇЇ ОЦННЮВАННЯ}

\begin{abstract}
Increasing the innovative activity of enterprises requires a preliminary assessment of their innovation capacity and the implementation of its management measures. The purpose of this study was to establish the essence of the innovation capacity of enterprises and identify methods and indicators. It is shown that the innovative capacity of enterprises is their ability under certain environmental conditions to obtain the maximum possible value of financial and economic results of economic activity due to the introduction of innovations. The main approaches to the assessment of the level of the innovation capacity of enterprises depending on the means of such assessment used for this purpose are highlighted. It is shown that optimization is the most reasonable among these approaches. A hierarchy of indicators for assessing the innovation capacity of enterprises is proposed.
\end{abstract}

Keywords: enterprise, innovation capacity, evaluation, method, indicator, optimization approach.

Постановка проблеми. Забезпечення стійкого та довгострокового економічного розвитку підприємств потребує від їх власників та менеджерів розроблення та впровадження науково обгрунтованих стратегій інноваційної діяльності. При цьому формування інноваційних стратегій підприємств повинно базуватися на детальному аналізуванні їх здатності впроваджувати у власну господарську діяльність певні види продуктових, технологічних, маркетингових та інших нововведень. Також важливе значення має встановлення прогнозного впливу такого впровадження на доходи, прибутки та інші фінансово-економічні результати господарської діяльності підприємств. Для цього необхідно оцінити величину інноваційної ємності підприємств, що, своєю чергою, викликає потребу у належному методологічному забезпеченні процесу такого оцінювання. 
Аналіз останніх досліджень та публікацій. Питання оцінювання різних характеристик інноваційної діяльності підприємств розглядається у значній кількості наукових праць. Значних результатів у вирішенні цього питання досягли, зокрема, такі науковці, як А. В. Гриньов, В. А. Гришко, Г. І. Капінос, В. В. Козик, Ю. Ф. Кондратюк, С. В. Лапін, Л. І. Лігоненко, Л. М. Малярець, О. Б. Мусійовська, Л. П. Радченко, Ж. В. Семчук, Л. І. Федулова та ін. Ними було 3'ясовано сутність та запропоновано показники та методи оцінювання таких властивостей підприємства, як його інноваційний потенціал, інноваційна активність та інноваційна сприйнятливість. Також науковцями досліджено особливості формування та оцінювання такої достатньо загальної властивості підприємств як їх інноваційність. Водночас, питання визначення змісту такої характеристики суб'єктів господарювання як їх інноваційна ємність та розроблення дієвого методологічного забезпечення її оцінювання на теперішній час не $\epsilon$ повністю вирішеним і потребує подальшого дослідження.

Формулювання цілей статті. Метою статті $є$ встановлення сутності інноваційної ємності підприємств та виділення методів і показників ії оцінювання.

Виклад основного матеріалу дослідження. Серед перелічених вище властивостей, що характеризують інноваційну діяльність підприємств, найбільш дослідженим $є$ їх інноваційний потенціал. При цьому у науковій літературі існує чотири основні підходи до визначення сутності як сукупного потенціалу підприємства, так і його інноваційного потенціалу, а саме:

1) ресурсний підхід, згідно якого економічний потенціал підприємства ототожнюється із сукупністю його ресурсів, що характеризуються відповідними обсягами та споживчими властивостями. За такого підходу до визначення потенціалу під інноваційним потенціалом підприємства слід розуміти сукупність його інноваційних ресурсів - як наявних, так і можливих до залучення у майбутньому. Зокрема, А. В. Гриньов трактує інноваційний потенціал організації як сукупність усіх наявних матеріальних та нематеріальних активів підприємства, що використовуються в процесі здійснення інноваційної діяльності ${ }^{1}$;

2) функціональний підхід, згідно якого економічний потенціал підприємства тлумачиться як сукупність його можливостей виконувати певні функції (залучати ресурси, виробляти продукцію, збувати іiі та ін.). 3 цих позицій інноваційний потенціал підприємства можна трактувати як його здатність розробляти (впроваджувати) інновації. Так, Є. В. Лапін розглядає інноваційний потенціал підприємства як спроможність створювати нововведення власними силами або придбавати їх збоку, а також як ефективність впровадження інновацій в практику господарської діяльності²;

3) цільовий підхід. Цей підхід до тлумачення сутності потенціалу підприємства є певною мірою похідним від функціонального. Згідно цільового підходу потенціал підприємства розглядається через призму певних наперед обраних цілей його діяльності. Загалом, сукупність таких цілей характеризується значним різноманіттям та ієрархічною природою. Для прикладу, ними може виступати збільшення фінансових результатів, зростання ринкової вартості фірми, нарощування іiі частки на ринках збуту тощо. Більшість цілей підприємницької діяльності може досягатися у тому числі і за рахунок провадження інновацій. Отже, з цих позицій інноваційний потенціал підприємства являтиме собою його здатність досягати наперед обраних цілей своєї господарської діяльності. Так, Л. І. Федулова ототожнює інноваційний потенціал організації з мірою ії готовності виконати завдання, які забезпечують досягнення поставленої інноваційної мети;

4) комбінований підхід. Він стосується випадку, за якого тлумачення сутності потенціалу підприємства передбачає певне поєднання одночасно декількох 3 перелічених вище підходів до такого тлумачення. Зокрема, найчастіше в науковій економічній літературі поєднують ресурсний та функціональний підходи, як це робить В. В. Козик зі співавторами ${ }^{4}$. Якщо таке поєднання застосувати до визначення сутності інноваційного потенціалу підприємства, то тоді під цим потенціалом слід розуміти здатність підприємства розробляти (впроваджувати) нововведення завдяки наявним та можливим до залучення цим підприємством інноваційним ресурсам. Так, Г. І. Капінос й

\footnotetext{
${ }^{1}$ Гриньов, А. В. (2003). Оцінка інноваційного потенціалу підприємства. Проблеми науки, 12, 12-17.

2 Лапин Е. В. (2004). Оиенка экономического потенциила предприятия: монография. Сумы: Университетская книга.

${ }^{3}$ Федулова, Л. І. (2006). Перспективи інноваційного розвитку України. Економіка і прогнозування, 2, 58-76.

${ }^{4}$ Козик, В. В., Смельянов, О. Ю., Лесик, Л. І. (2014). Система показників оцінювання поточного рівня

ендогенного економічного потенціалу підприємств. Економічний простір, 86, 173-184.
} 
О. М. Радюк пропонують розглядати інноваційний потенціал підприємства як його сукупні можливості щодо ефективного впровадження нових технологій у господарський обіг ${ }^{1}$.

Розглядаючи закономірності формування інноваційного потенціалу підприємства, важливо також відзначити існування його наявного та перспективного (майбутнього, прогнозного) рівнів. При цьому наявний рівень інноваційного потенціалу зумовлений існуючими у підприємствами обсягами інноваційних ресурсів та їх споживчими властивостями. Стосовно перспективного інноваційного потенціалу, то як зазначає В. А. Гришко зі співавторами, його величина визначається не лише наявними інноваційними ресурсами, але й можливостями підприємства щодо їх додаткового залучення (в окремих випадках - вилучення) ${ }^{2}$.

Стосовно таких властивостей підприємств як інноваційна сприйнятливість та інноваційність, то закономірності їх формування досліджено не так всебічно, як закономірності утворення інноваційного потенціалу суб'єкта господарювання. При цьому у більшості наукових праць інноваційна сприйнятливість підприємства зводиться до його здатності (наявної або потенційної) залучати нововведення у свою діяльність або залучати інформацію, потрібну для започаткування на підприємстві відповідних інноваційних процесів. Зокрема, такої думки додержується О. Б. Мусійовська ${ }^{3}$, якою також пропонується оцінювати іншу властивість інноваційної діяльності підприємств, а саме - їх інноваційну активність за допомогою відносних показників. Одним з таких показників є частка доходів від інноваційної діяльності у загальній величині виручки від реалізації продукції підприємством у звітному періоді.

Стосовно інноваційності суб'єкта господарювання, то вона трактується переважно з позицій тієї ролі, яку відіграють інновації у діяльності конкретного підприємства, як це, зокрема, робить Л. П. Радченко ${ }^{4}$. Отже, інноваційність $є$ властивістю підприємства, яка характеризує міру використання інновацій у його господарській діяльності. При цьому, як відзначається у роботі Л. І. Лігоненко, ця міра може описуватися за допомогою різноманітних показників ${ }^{5}$.

Порівняно із переліченими вище властивостями інноваційної діяльності підприємств їх інноваційну ємність досліджено значно менше. При цьому термін «ємність» використовується у науковій економічній літературі переважно у контексті характеристики ринків збуту продукції, як це роблять Л. М. Малярець та Д. В.Великородна ${ }^{6}$. Якщо ж розглядати рівень підприємства, то вживається термін «інвестиційна ємність підприємства». Зокрема, це роблять Ж. В. Семчук та Р. М. Скриньковськийㄱ. За допомогою цього терміну переважно описується здатність підприємства залучати інвестиції з метою фінансування заходів з простого та розширеного відтворення своєї діяльності.

Стосовно терміну «інноваційна ємність», то у науковій літературі це поняття зустрічається переважно у контексті науковомісткості. Зокрема, такий підхід застосовує Ю. Ф. Кондратюк ${ }^{8}$. Водночас, інноваційна ємність як характеристика підприємства досліджена недостатньо.

На підставі встановлення співвідношень між переліченими властивостями інноваційної діяльності підприємств можливо визначити сутність кожної з них (табл. 1) та встановити місце

\footnotetext{
${ }^{1}$ Капінос, Г. І., Радюк О. М. (2007). Інноваційний потенціал підприємства: сутність, складові та принципи формування. Наука й економіка, 2 (6), 130-136.

${ }^{2}$ Гришко, В. А., Смельянов, О. Ю., Крет, І. 3. (2010). Оцінювання поточного та стратегічного рівня інвестиційного потенціалу машинобудівних підприємств. Вісник Національного університету «Львівська політехніка». Проблеми економіки та управління, 683, 210-215.

${ }^{3}$ Мусійовська О. Б. (2014). Економічне оцінювання та управління інноваційною сприйнятливістю машинобудівних підприємств: дисертація на здобуття наукового ступеня кандидата економічних наук. Львів: Національний університет «Львівська політехніка».

${ }^{4}$ Радченко, Л. П. (2019). Інноваційність національної економіки в контексті людського розвитку. Вчені записки ТНУ імені В. І. Вернадського. Серія: Економіка і управління, 30 (69), 1-5.

5 Лігоненко, Л. І. (2015). Методологія та інструментарій оцінювання інноваційності підприємства. Маркетинг іменеджмент інновачій, 3, 105-117.

${ }_{6}^{6}$ Малярець, Л. М., Великородна, Д. В. (2012). Визначення місткості ринку інформаційних продуктів та послуг регіону. Проблеми економіки, 2, 12-15.

${ }^{7}$ Семчук, Ж. В., Скриньковський, Р. М. (2015). Система діагностики інвестиційної діяльності підприємства: теоретичні засади та методичні положення. Агросвіт, 8, 12-17.

${ }^{8}$ Кондратюк, Ю. Ф. (2016). Продуктивність праці як чинник забезпечення людського розвитку: дисертація на здобуття наукового ступеня кандидата економічних наук. Київ: Інститут демографії та соціальних досліджень ім. М. В. Птухи.
} 
інноваційної ємності серед них (табл. 2). Зокрема, інноваційний потенціал підприємства доцільно розглядати як характеристику здатності підприємства розробляти нововведення власними силами. Водночас, інноваційна ємність підприємства характеризуватиме потенційну здатність підприємства впроваджувати у свою діяльність різні види нововведень.

Таблиця 1

\section{Тлумачення сутності головних властивостей, які характеризують інноваційну діяльність підприсмств}

\begin{tabular}{|l|l|}
\hline \multicolumn{1}{|c|}{ Назви властивостей } & \multicolumn{1}{|c|}{ Тлумачення сутності властивостей } \\
\hline $\begin{array}{l}\text { 1. Інноваційна активність } \\
\text { підприємства }\end{array}$ & $\begin{array}{l}\text { Міра проведених підприємством досліджень та розробок } \\
\text { у звітному періоді }\end{array}$ \\
\hline $\begin{array}{l}\text { 2. Інноваційна сприйнятливість } \\
\text { підприємства }\end{array}$ & $\begin{array}{l}\text { Міра впроваджених у діяльність підприємства нововведень } \\
\text { (як розроблених власними силами, так і залучених зі сторони) } \\
\text { у звітному періоді }\end{array}$ \\
\hline 3. Інноваційність підприємства & $\begin{array}{l}\text { Міра інтенсивності інноваційних процесів на підприємстві } \\
\text { у звітному періоді. }\end{array}$ \\
\hline $\begin{array}{l}\text { 4. Інноваційний потенціал } \\
\text { підприємства }\end{array}$ & $\begin{array}{l}\text { Здатність підприємства до отримання максимально можливої } \\
\text { величини фінансово-економічних показників його господарської } \\
\text { діяльності завдяки розробленню нововведень та їх подальшому } \\
\text { використанню (комерціалізації) на базі наявних та можливих } \\
\text { до залучення цим підприємством інноваційних ресурсів } \\
\text { за певних умов зовнішнього середовища, у якому перебуватиме } \\
\text { це підприємство. }\end{array}$ \\
\hline $\begin{array}{l}\text { 5. Інноваційна ємність } \\
\text { підприємства }\end{array}$ & $\begin{array}{l}\text { Здатність підприємства до отримання максимально можливої } \\
\text { величини фінансово-економічних показників його господарської } \\
\text { діяльності завдяки впровадженню у його діяльність нововведень, } \\
\text { як розроблених власними силами, так і залучених зі сторони } \\
\text { за певних умов зовнішнього середовища, у якому перебуватиме } \\
\text { це підприємство }\end{array}$ \\
\hline
\end{tabular}

Джерело: запропоновано авторами на основі аналізування літературних джерел

Таблиця 2

\section{Співвідношення між властивостями підприємства у сфері провадження ним інноваційної діяльності}

\begin{tabular}{|c|c|c|c|}
\hline \multicolumn{4}{|c|}{ Властивості, які характеризують інноваційну діяльність підприємств } \\
\hline \multicolumn{2}{|c|}{ На стадії розроблення нововведень } & \multicolumn{2}{|c|}{ На стадії впровадження нововведень } \\
\hline $\begin{array}{c}\text { Характеристика прогнозного } \\
\text { рівня здійснення } \\
\text { інноваційної діяльності }\end{array}$ & \multicolumn{2}{|c|}{$\begin{array}{c}\text { Характеристика фактичного рівня } \\
\text { здійснення інноваційної діяльності } \\
\text { підприємства }\end{array}$} & $\begin{array}{c}\text { Характеристика прогнозного } \\
\text { рівня здійснення інноваційної } \\
\text { діяльності }\end{array}$ \\
\hline \multirow[t]{2}{*}{$\begin{array}{c}\text { Інноваційний потенціал } \\
\text { підприємства }\end{array}$} & $\begin{array}{c}\text { Інноваційна } \\
\text { активність } \\
\text { підприємства }\end{array}$ & $\begin{array}{c}\text { Інноваційна } \\
\text { сприйнятливість } \\
\text { підприємства }\end{array}$ & \multirow[t]{2}{*}{$\begin{array}{c}\text { Інноваційна ємність } \\
\text { підприємства }\end{array}$} \\
\hline & \multicolumn{2}{|c|}{ Інноваційність підприємства } & \\
\hline
\end{tabular}

\section{Джерело: розроблено авторами}

Необхідно відзначити той факт, що інноваційна ємність підприємства має достатньо складну структуру. Зокрема, як випливає зданих табл. 3, можливо виділити іiі реалізовану частину (інноваційну місткість), яка характеризує сукупність тих нововведень, які було успішно впроваджено у діяльність підприємства у попередніх періодах і які ще зберігають ознаки їхньої інноваційності, та нереалізовану частину, яка характеризує сукупність тих нововведень, які ще не було впроваджено 
у діяльність підприємства у попередніх періодах, але впровадження яких є можливим та доцільним. Своєю чергою, нереалізована інноваційна ємність підприємства може поділятися на низьку (iї реалізація забезпечить зростання відповідного виду фінансово-економічних результатів діяльності підприємства на величину, що не перевищує одного відсотка від їх теперішнього обсягу), середню (iі реалізація забезпечить зростання відповідного виду фінансово-економічних результатів діяльності підприємства на величину, що більша одного відсотка, але не перевищує п’яти відсотків від їх теперішнього обсягу) та високу (iї реалізація забезпечить зростання відповідного виду фінансово-економічних результатів діяльності підприємства на величину, що перевищує п’ять відсотків від їх теперішнього обсягу).

Таблиця 3

Склад інноваційної ємності підприємства

\begin{tabular}{|c|c|c|c|c|c|c|c|}
\hline \multicolumn{7}{|c|}{ Інноваційна ємність підприємства } & \multicolumn{2}{|c|}{$\begin{array}{c}\text { Нереалізована } \\
\text { iнноваційна ємність }\end{array}$} \\
\hline \multicolumn{3}{|c|}{ Реалізована інноваційна ємність (інноваційна місткість підприємства) } & Уи- \\
\multirow{2}{*}{$\begin{array}{c}\text { Зага- } \\
\text { льна }\end{array}$} & Продуктова & Технічна & Соціальна & $\begin{array}{c}\text { Господар- } \\
\text { ська }\end{array}$ & $\begin{array}{c}\text { Органі- } \\
\text { заційна }\end{array}$ & $\begin{array}{c}\text { Висо- } \\
\text { зька } \\
\text { ка }\end{array}$ \\
\hline
\end{tabular}

Джерело: розроблено авторами

Слід відзначити, що на теперішній час у науковій літературі не представлено належних засобів оцінювання інноваційної ємності підприємств. Тому доцільно систематизувати існуючі методи оцінювання економічного потенціалу підприємства загалом та, зокрема, його інноваційного потенціалу. Внаслідок цього, видається доцільним виділити шість таких основних методів оцінювання економічних можливостей підприємства i, зокрема, інноваційної ємності:

1) підхід, що базується на вимірюванні обсягів наявних у підприємства ресурсів та їх споживчих характеристик (ресурсно-аналітичний підхід). Такими характеристиками можуть виступати прогресивність використовуваних матеріалів та наявних технічних ресурсів, кваліфікація працівників тощо. Цей підхід до оцінювання економічного потенціалу організації $є$ позитивним з точки зору широти та значного охоплення досліджуваних об'єктів, тобто базових складників економічних можливостей підприємства. Проте, згідно описаного підходу поза вивченням залишаються компетенції працівників підприємства. Також цей підхід не використовує узагальнюючі показники оцінювання економічного потенціалу підприємств або окремого виду цього потенціалу. Крім того, не передбачається проведення пошуку резервів зростання економічних можливостей підприємств;

2) оцінювання шляхом обгрунтування рівня використання ресурсів підприємств, зокрема, завдяки нормуванню витрат виробничих ресурсів із зіставленням результатів такого нормування 3 фактичними витратами цих ресурсів (нормувальний підхід). Тоді з'являється можливість встановлення резервів покращення застосування ресурсів підприємства та невикористаних можливостей нарощування його фінансово-економічних результатів. Водночас, слід враховувати той факт, що далеко не всі показники використання ресурсів можуть бути пронормованими. Крім того, описаний підхід не передбачає застосування узагальнюючого показника оцінювання й не бере до уваги зовнішнє середовище господарюючого суб' єкта;

3) оцінювання, що базується на експертних оцінках (експертно-оціночний підхід). Зокрема, мова йде про рівень значущості часткових показників, які, своє чергою, описують ті чи інші чинники формування сукупних економічних можливостей підприємства або певних їх різновидів (зокрема, інноваційних можливостей). Позитивною особливістю цього підходу до оцінювання економічних можливостей господарюючих суб’єктів $€$ те, що він передбачає побудову узагальнюючого індикатора такого оцінювання. Зокрема, таким показником може виступати сума добутків нормованих значень часткових показників на коефіцієнти їхньої значущості. Разом з тим, експертні оцінки часто страждають високою суб'єктивністю. Також не достатньо обгрунтованим виглядає відбір часткових показників та спосіб їх поєднання при розрахунку узагальнюючого показника оцінювання; 
4) оцінювання на засадах зіставлення часткових показників діяльності досліджуваного підприємства із цими ж показниками іншого підприємства (як правило, ним обирається галузевий лідер) або середньогалузевими показниками з подальшим обчисленням узагальнюючого індикатора із застосуванням результатів експертного опитування (порівняльний підхід). За своєю суттю цей підхід до оцінювання рівня економічних можливостей підприємств $\epsilon$ розвитком попереднього і йому властиві усі головні його недоліки;

5) оптимізаційний підхід, згідно якого виконується обчислення значень параметрів, що впливають на величину економічного потенціалу організації, за яких відбувається максимізація наперед обраного результату іiі діяльності (зокрема, таким результатом (цільовою функцією оптимізації) може виступати ринкова вартість суб'єкта господарювання). Цей підхід до оцінювання економічних можливостей підприємства слід вважати найбільш обгрунтованим. Зокрема, його доцільно застосовувати і у випадку оцінювання інноваційної ємності суб'єкта господарювання. Разом 3 тим, важливо правильно встановити механізм проведення оптимізації, зокрема, стосовно виділення параметрів, що впливають на величину економічного потенціалу організації, а також визначення взаємозв'язку між цими параметрами;

6) комбіновані підходи, за яких відбуваються певні поєднання описаних вище методологічних підходів до оцінювання величини економічних можливостей суб'єктів господарювання.

Отже, найбільш обгрунтованим підходом до оцінювання економічних можливостей підприємства та, зокрема, його інноваційної ємності є оптимізаційний підхід, оскільки у процесі господарської діяльності підприємство повинно прагнути максимізувати рівень ії економічної ефективності. Цей підхід відповідає i запропонованому нами раніше тлумаченню сутності інноваційної ємності суб’єкта господарювання.

Оцінювання інноваційної ємності підприємства, серед іншого, потребує попереднього обчислення показників, що характеризуватимуть чинники формування цієї ємності. Базуючись на виконаному дослідженні ієрархії чинників формування інноваційної ємності підприємств, пропонується чотирьохрівнева модель оцінювання цієї ємності, яка включатиме групи показників, представлені у табл. 4. При цьому показники оцінювання інноваційної ємності підприємств нижчого рівня визначають величину показників більш високого рівня представленої ієрархії індикаторів.

Таблиця 4

Ієрархія показників оцінювання інноваційної смності підприсмства

\begin{tabular}{|c|l|l|}
\hline Рівні ієрархії & \multicolumn{1}{|c|}{ Назви груп показників } & \multicolumn{1}{|c|}{ Види показників } \\
\hline I & $\begin{array}{l}\text { Базові показники } \\
\text { оцінювання } \\
\text { інноваційної ємності }\end{array}$ & $\begin{array}{l}\text { Показники рівня компетенцій власників, менеджерів та } \\
\text { фахівців підприємста у сфері управління його інноваційною } \\
\text { діяльністю; показники рівня інформаційного забезпечення } \\
\text { процесу управління інноваційною діяльністю }\end{array}$ \\
\hline II & $\begin{array}{l}\text { Часткові показники } \\
\text { оцінювання } \\
\text { інноваційної ємності }\end{array}$ & $\begin{array}{l}\text { Показники споживчих властивостей ресурсів підприємства; } \\
\text { показники споживчих властивостей інноваційної продукції } \\
\text { підприємства; показники собівартості інноваційної продукції } \\
\text { підприємства; показники обсягів різних видів ресурсів } \\
\text { підприємства; показники попиту на інноваційну продукцію } \\
\text { підприємства }\end{array}$ \\
\hline III & $\begin{array}{l}\text { Загальні показники } \\
\text { оцінювання } \\
\text { інноваційної ємності }\end{array}$ & $\begin{array}{l}\text { Показник оптимальних обсягів інноваційної діяльності } \\
\text { підприємства; показник рівня ефективності інноваційної } \\
\text { діяльності підприємства, який відповідає ії оптимальним } \\
\text { обсягам }\end{array}$ \\
\hline IV & $\begin{array}{l}\text { Узагальнюючий } \\
\text { показник оцінювання } \\
\text { інноваційної ємності }\end{array}$ & $\begin{array}{l}\text { Максимально можливе значення певного виду фінансово- } \\
\text { економічних результатів діяльності підприємства за умови } \\
\text { повної реалізації наявної у підприємства інноваційної ємності }\end{array}$ \\
\hline
\end{tabular}

Джерело: розроблено авторами

Використання представленої у табл. 4 ієрархії показників оцінювання інноваційної ємності підприємств у практиці їх діяльності дасть змогу встановити обгрунтовані обсяги провадження суб’єктами господарювання своєї інноваційної діяльності. 
Висновки. Інноваційна ємність підприємства являє собою його здатність до отримання максимально можливої величини фінансово-економічних показників його господарської діяльності завдяки впровадженню у його діяльність нововведень, як розроблених власними силами, так i залучених зі сторони за певних умов зовнішнього середовища, уякому перебуватиме це підприємство. При цьому найбільш обгрунтованим підходом до оцінювання інноваційної ємності підприємства $є$ оптимізаційний підхід, оскільки у процесі господарської діяльності підприємство повинно прагнути максимізувати рівень її економічної ефективності. Цей підхід використано при побудові запропонованої у статті ієрархії показників оцінювання інноваційної ємності підприємств. Подальші дослідження повинні передбачати встановлення зв'язку цієї ієрархії із інструментами управління інноваційною ємністю суб'єктів господарювання.

\section{References:}

1. Hrynov, A. V. (2003). Otsinka innovatsiinoho potentsialu pidpryiemstva [Assessment of the innovative potential of the enterprise]. Problemy nauky [Problems of science], 12, 12-17. [in Ukrainian].

2. Lapin, E. V. (2004). Ocenka jekonomicheskogo potenciala predprijatija: monografija [Assessment of the economic potential of the enterprise: monograph]. Sumy: Universitetskaja kniga. [in Russian].

3. Fedulova, L. I. (2006). Perspektyvy innovatsiinoho rozvytku Ukrainy [Prospects for innovative development of Ukraine]. Ekonomika i prohnozuvannia [Economics and forecasting], 2, 58-76. [in Ukrainian].

4. Kozyk, V. V., Yemelyanov, O. Yu., Lesyk, L. I. (2014). Systema pokaznykiv otsiniuvannia potochnoho rivnia endohennoho ekonomichnoho potentsialu pidpryiemstv [System of indicators for assessing the current level of endogenous economic potential of enterprises]. Ekonomichnyi prostir [Economic space], 86, 173-184. [in Ukrainian].

5. Kapinos, H. I., Radiuk, O. M. (2007). Innovatsiinyi potentsial pidpryiemstva: sutnist, skladovi ta pryntsypy formuvannia [Innovative potential of the enterprise: essence, components and principles of formation]. Nauka y ekonomika [Science and economics], 2(6), 130-136. [in Ukrainian].

6. Hryshko, V. A., Yemelyanov, O. Yu., Kret, I. Z. (2010). Otsiniuvannia potochnoho ta stratehichnoho rivnia investytsiinoho potentsialu mashynobudivnykh pidpryiemstv [Assessment of the current and strategic level of investment potential of machine-building enterprises]. Visnyk Natsionalnoho universytetu «Lvivska politekhnika» Problemy ekonomiky ta upravlinnia [Bulletin of the Lviv Polytechnic National University Problems of Economics and Management], 683, 210-215. [in Ukrainian].

7. Musiiovska O. B. (2014). Ekonomichne otsiniuvannia ta upravlinnia innovatsiinoiu spryiniatlyvistiu mashynobudivnykh pidpryiemstv [Economic evaluation and management of innovative susceptibility of machinebuilding enterprises]: dysertatsiya na zdobuttya naukovoho stupenya kandydata ekonomichnykh nauk [the dissertation on competition of a scientific degree of the candidate of economic sciences]. Lviv: Natsionalnyi universytet «Lvivska politekhnika». [in Ukrainian].

8. Radchenko, L. P. (2019). Innovatsiinist natsionalnoi ekonomiky v konteksti liudskoho rozvytku [Innovativeness of the national economy in the context of human development]. Vcheni zapysky TNU imeni V. I. Vernadskoho. Seriia: Ekonomika i upravlinnia [Scientific notes of TNU named after V. I. Vernadsky. Series: Economics and Management], 30(69), 1-5. [in Ukrainian].

9. Lihonenko, L. I. (2015). Metodolohiia ta instrumentarii otsiniuvannia innovatsiinosti pidpryiemstva [Methodology and tools for assessing the innovation of the enterprise]. Marketynh i menedzhment innovatsii [Marketing and Management of Innovations], 3, 105-117. [in Ukrainian].

10. Maliarets, L. M., Velykorodna, D. V. (2012).Vyznachennia mistkosti rynku informatsiinykh produktiv ta posluh rehionu [Determining the market capacity of information products and services in the region]. Problemy ekonomiky [Problems of the economy], 2, 12-15. [in Ukrainian].

11. Semchuk Zh. V., Skrynkovskyi R. M. (2015). Systema diahnostyky investytsiinoi diialnosti pidpryiemstva: teoretychni zasady ta metodychni polozhennia [The system of diagnostics of investment activity of the enterprise: theoretical bases and methodical provisions]. Ahrosvit [Agrarian world], 8, 12-17. [in Ukrainian].

12. Kondratiuk, Yu. F. (2016). Produktyvnist pratsi yak chynnyk zabezpechennia liudskoho rozvytku [Labor productivity as a factor in ensuring human development]: dysertatsiya na zdobuttya naukovoho stupenya kandydata ekonomichnykh nauk [the dissertation on competition of a scientific degree of the candidate of economic sciences]. Kyiv: Instytut demohrafii ta sotsialnykh doslidzhen im. M. V. Ptukhy. [in Ukrainian]. 